\title{
ANALYSIS OF CATFISH VALUE CHAIN IN AKWA IBOM STATE, NIGERIA
}

\author{
Akaninyene Obot $^{1 \bowtie}$, Osuafor Ogonna ${ }^{1}$, Chilaka Precious ${ }^{1}$, Antiaobong Essien ${ }^{2}$ \\ ${ }^{1}$ Nnamdi Azikiwe University, Awka, Anambra State, Nigeria \\ ${ }^{2}$ Akwa Ibom State University, Obio Akpa, Nigeria
}

\begin{abstract}
Capture fisheries production has increased sharply, and its contribution to economic growth of the region and welfare of the people in Akwa Ibom State have been quite significant. Up to now, micro-analyses of artisanal and capture fisheries, especially catfish (Clarias gariepinus) have often been carried out. Nevertheless, the competitiveness analysis of catfish capture is still limited; also, there is lack of development policies for capture and artisanal fisheries based on economic analyses. Therefore, this paper aims to come up with economic policies supporting the development of artisanal and capture fisheries in Akwa Ibom State. Data was collected in Akwa Ibom State. The types of data used include catfish value chain data, and farmers' costs and incomes. The Policy Analysis Matrix (PAM) method was used to reach the objective of this study. The study found that the Private Cost Ratio (PCR) was 0.61 for producers, 0.96 for processors and 0.59 for marketers which means that the production of agricultural goods was profitable for the farmers. In turn, the Domestic Resources Cost Ratio (DRC) was 0.17 for producers, 0.65 for processors and 0.34 for marketers, meaning that the value of domestic resources used in production is lower than the value of foreign exchange earned or saved; this indicates that the industry might have a comparative advantage. Research implications showed that the catfish fisheries business generated economic and financial benefits for local fishermen. It would be more advantageous to be able to compete with catfish from other regions as well as other countries, particularly if supported by government policies for a consistent and sustainable stabilization of input prices and production output of catfish fisheries.
\end{abstract}

Keywords: policy analysis matrix, competitiveness, profitability

\section{INTRODUCTION}

Fish production is very important not only as a source of animal protein to ensure food security but also as a way to improve employment and income towards the elimination of poverty in developing countries (Okezie et al., 2008). Flake and Nzeke (2007) stated that fish are the cheapest source of animal protein and represent a significant proportion of animal protein in the diet of most developing countries, including Nigeria. Globally, fish account for about $17 \%$ of animal protein intake and $6.7 \%$ of all protein consumed by humans (FAO, 2016).

The Nigerian fisheries sub-sector contributes about $3-4 \%$ to the country's GDP and is an important contributor to the population's nutritional requirements, constituting about $50 \%$ of animal protein intake. In addition, the sub-sector generates employment and income for a significant number of artisanal fishermen and small traders. Although capture fisheries has now been declining, Nigeria has a big potential in both marine and freshwater fisheries, including aquaculture. In spite of this high potential, domestic fish production still falls far below total demand, estimated at 2.2 million metric tons per year in 2008. As a result, the country imports about $60 \%$ of fish consumed. To reduce the level of fish imports, aquaculture has been selected as one of the priority value chains targeted for development in the next four years. The National Aquaculture Strategy Plan has just been finalized with the assistance of FAO to guide support for the value chain (FAO, 2020). The contribution of

\footnotetext{
$凶$ Akaninyene Obot, Department of Agricultural Economics and Extension, Nnamdi Azikiwe University, Awka, Anambra State, e-mail: ap.obot@unizik.edu.ng, https://orcid.org/0000-0001-8775-4064
} 
fisheries to the nation's economy is very significant in terms of employment. In Nigeria, the sub-sector is estimated to employ over 8.6 million people directly and a further 19.6 million indirectly (WorldFish, 2018).

There are two main sources of fish in Nigeria (domestic production and imports). The domestic component consists of artisanal fishing and fish farming, the latter of which involves rearing fish to a marketable size in an enclosed water body (Ogundari and Ojo, 2009; Olawumi et al., 2010). Fish farming mainly supplements the unpredictable production from capture (natural stock)/artisanal fisheries. Though it has been practiced in Nigeria for over forty years, fish farming has not contributed notably to domestic production figures. The total fish demand for Nigeria, based on the 2014 population estimate of 180 million, was 3.32 million tons, and the domestic fish production from aquaculture, artisanal fishing and industrial fisheries in 2014 was 1.123 million tons (Fishery Committee..., 2016). In 2015, fisheries including aquaculture, contributed $0.5 \%$ to the Gross Domestic Product (GDP) of Nigeria (Central Bank of Nigeria, 2015). There is the potential to increase domestic production as the country has more than 12 million hectares of inland waters suitable for fish farming development (Inoni, 2007).

Fish production in the Niger Delta is dominated by smallholder producers. Smallholder fish production is broadly characterized as a dynamic and evolving subsector that employs labor-intensive harvesting, processing and distribution technologies to exploit marine and inland water resources (FAO, 2005; Béné, 2006; Béné et al., 2007). The activities of this sub-sector, conducted full-time, part-time or just seasonally, are often targeted at supplying fish and fisheries products to local and domestic markets, and may also be intended for subsistence consumption (FAO, 2005; Béné, 2006; Béné et al., 2007). Fishing is one of the main economic activities in the Niger Delta region, with about $40-60 \%$ of the labor force engaged in it (Ekpo and Essien-Ibok, 2013). Fishing, as a major occupation of the region, provides an estimated $50 \%$ of fish consumed in Nigeria (Béné and Neiland, 2004; Uyigue and Agho, 2007). Considering the persistent conflict in the region, damage to its environment due to crude oil spillage, and the rising unemployment rate (National Bureau of Statistics, 2013; 2016; United Nations Environment Program, 2011), fish farming provides a potential alternative means of self-employment in the region. The development of fish farms will help create employment opportunities, provide income, reduce poverty, address incessant conflicts and serve as an alternative to capture fishing that is no longer economically sustainable to inhabitants of most communities in the region due to oil spills.

A value chain approach means taking a whole-ofchain perspective of primary producers and their input suppliers, passing through every stage until the product reaches the end consumer. It examines the flows of products, money and information, with a focus on how these are influenced by the relationships between chain actors. Of particular importance is the need to understand markets and consumers, and the state of collaboration inside the chain. A value chain approach highlights how effective partners can better align their skills, resources and behavior to deliver products and services to different market segments and to reduce waste, with the resultant financial returns being distributed equitably so as to sustain partnerships within the chain. This improves the competitiveness of each business, and helps chain actors to recognize their interdependence and the consequent benefits of solving shared problems (Akande, 2018). Adeniyi (2013) defined value chain as the full range of activities which are required to bring a product from conception, through the different phases of production (involving a combination of physical transformation and the input of various producer services), to the delivery to final consumers. It is necessary to recognize the importance of fish within the agriculture sector for its potential contribution to alleviating poverty, improving food and nutrition security, reducing youth unemployment and building profitable business ventures. Capture fisheries and aquaculture are gaining increased attention, in both the public and private sectors. With the continuous increase in aquaculture's contribution to total fish production, and with value addition in the catfish industry, post-harvest losses will be minimized; catfish farmers will earn more income from their endeavors; food security will be better enhanced; and fish exports will be promoted.

The current population of Nigeria is 193.976 million (FAOSTAT, 2018). With an estimated annual per capita fish consumption of $17.5 \mathrm{~kg}$ (according to FAO), the projected fish demand for 2018 in Nigeria is 3.61 million metric tons (FDF, 2018). Nigeria is the largest consumer of fish products in Africa. Over the years, Nigeria has relied on fish imports to meet the ever-increasing national demand. FAO reported that Nigeria is a net 
Obot, A., Ogonna, O., Precious, Ch., Essien, A. (2020). Analysis of catfish value chain in Akwa Ibom State, Nigeria. J. Agribus. Rural Dev., 1(55), 53-60. http://dx.doi.org/10.17306/J.JARD.2020.01305

importer of fishery products, with total fish imports amounting to about USD 1.2 billion and exports valued at USD 284,390 million in 2013. Several efforts have been made to implement policies and programs to bridge the gap between demand for and supply of fish in Nigeria. Aquaculture fishery in Nigeria has gained positive growth as a result of proper implementation of some of these programs, growing from 21,700 tons recorded in 1999 to $316,727.00$ tons in 2015. This has put Nigeria as the largest aquaculture producer in subSaharan Africa. This role is steadily strengthened at an average annual growth rate of 20,000 tons of cultured fish. Considering the significant growth in the Nigerian aquaculture sector, there is the need to give all fisheries sub-sectors the required attention to effectively bridge the gap between fish demand and supply. Hence, the objective of this study was to assess the competitiveness and profitability of the catfish value chain in Akwa Ibom State. The study examined the catfish value chain with a view to providing recommendations for further increasing the competitiveness of this industry.

\section{MATERIALS AND METHODS}

In Nigeria, fish alone contribute on the average $20-25 \%$ to per capita animal intake. This ratio could be as high as $80 \%$ in coastal and riverine communities (FAO, 2000a). FAO provides estimates of the projected population and fish demand and supply from 1997 to 2025 . The domestic fish production figure for 2015 was 1.12 million tons (FAO, 2000a), see Table 1 below:

The Niger Delta is located on the Atlantic coast of southern Nigeria where river Niger divides into numerous tributaries (Awosika, 1995). The area lies at latitudes between $4^{\circ} 15^{\prime} \mathrm{N}$ and $6^{\circ} 30^{\prime} \mathrm{N}$ and at longitudes between $4^{\circ} 30^{\prime} \mathrm{E}$ and $8^{\circ} 30^{\prime} \mathrm{E}$ (Onojeghuo and Blackburn, 2011). The region spans over 70,000 square kilometers and has been described as the largest wetland in Africa. About 2,370 square kilometers of the Niger Delta area consist of rivers, creeks and estuaries. Stagnant swamps cover ca. 8,600 square kilometers (Etiosa and Ogbeibu, 2007). The region cuts across the nine oil producing states in southern Nigeria, including Abia, Akwa-Ibom, Bayelsa, Cross River, Delta, Edo, Imo, Ondo and Rivers. Fishing, farming, and petty trading are the predominant economic activities of the region.

The study was conducted in Akwa Ibom, a state richly endowed with abundant inland water bodies, flood
Table 1. Projected population and fish demand/supply, 2000 $-2025$

\begin{tabular}{|c|c|c|c|c|}
\hline Year & $\begin{array}{l}\text { Population } \\
\text { (million) }\end{array}$ & $\begin{array}{l}\text { Fish demand } \\
(\text { million } \mathrm{t})\end{array}$ & $\begin{array}{c}\text { Fish supply } \\
\text { (domestic } \\
\text { production) } \\
\text { (million } \mathrm{t} \text { ) }\end{array}$ & $\begin{array}{c}\text { Shortfall } \\
\text { (million } \mathrm{t})\end{array}$ \\
\hline 2000 & 114.40 & 0.87 & 0.53 & 0.34 \\
\hline 2001 & 117.60 & 0.89 & 0.57 & 0.32 \\
\hline 2002 & 121.00 & 0.92 & 0.61 & 0.31 \\
\hline 2003 & 124.40 & 0.95 & 0.65 & 0.30 \\
\hline 2004 & 127.90 & 0.97 & 0.69 & 0.28 \\
\hline 2005 & 131.50 & 1.00 & 0.73 & 0.27 \\
\hline 2006 & 135.20 & 1.03 & 0.77 & 0.26 \\
\hline 2007 & 139.10 & 1.06 & 0.81 & 0.25 \\
\hline 2008 & 143.00 & 1.09 & 0.85 & 0.24 \\
\hline 2009 & 147.10 & 1.12 & 0.89 & 0.23 \\
\hline 2010 & 151.20 & 1.15 & 0.93 & 0.22 \\
\hline 2011 & 155.50 & 1.18 & 0.96 & 0.21 \\
\hline 2012 & 159.90 & 1.22 & 1.00 & 0.22 \\
\hline 2013 & 164.40 & 1.25 & 1.04 & 0.21 \\
\hline 2014 & 169.10 & 1.29 & 1.08 & 0.21 \\
\hline 2015 & 173.90 & 1.32 & 1.12 & 0.20 \\
\hline 2016 & 178.80 & 1.36 & 1.16 & 0.20 \\
\hline 2017 & 183.30 & 1.39 & 1.20 & 0.19 \\
\hline 2018 & 189.00 & 1.44 & 1.24 & 0.20 \\
\hline 2019 & 194.40 & 1.48 & 1.28 & 0.20 \\
\hline 2020 & 199.90 & 1.52 & 1.32 & 0.20 \\
\hline 2021 & 205.60 & 1.56 & 1.36 & 0.20 \\
\hline 2022 & 211.40 & 1.61 & 1.40 & 0.21 \\
\hline 2023 & 217.40 & 1.65 & 1.44 & 0.21 \\
\hline 2024 & 223.50 & 1.70 & 1.48 & 0.22 \\
\hline 2025 & 229.80 & 1.75 & 1.52 & 0.23 \\
\hline
\end{tabular}

Source: FAO, 2000b.

plains and wetlands which are highly productive and ideal for artisanal fisheries and aquaculture development (Akwa Ibom State Economic Empowerment and Development Strategy (SEEDS, 2005). 
Located in south Nigeria, Akwa Ibom is one of the fish producing states. It is located at latitudes between $4^{\circ} 31^{\prime}$ and $5^{\circ} 31^{\prime}$ 'north and longitudes between $7^{\circ} 35^{\prime}$ and $8^{\circ} 35^{\prime}$ ' east; it occupies a total land area of 7,254,935 square kilometers and has an estimated population of 3,920,208 (NPC, 2006). It also has a major concentration of fish farmers. The Akwa Ibom State fish industry has been a major player in the local economy and a means of livelihood for the citizens. All farmers registered in the industry are situated in single, well laid-out industrial locations. Data on the costs of and returns from fish production, processing and marketing was collected from operators active in the industry.

The key informants, i.e. major producers, processors and marketers, provided an initial overview of the industry. On that basis, the industry was categorized into three groups, namely: production, processing and marketing. Data on costs and returns was collected from purposively selected operators, based on the availability of records on fishing operations. Data was collected through personal interviews, direct observation and data extraction from the records.

Four local government areas were selected based on their prominence in the fish industry: Ikot Ekpene, Itu, Uruan and Mbo. Data was collected from a sample of 135 catfish farmers stratified into producers, processors and marketers ( 45 producers, 45 processors and 45 marketers) using a pre-tested questionnaire.

Primary data used in this study came from questionnaires administered to 135 catfish farmers. The questionnaires were developed based on a literature review and discussions with catfish industry experts. There were three questionnaires, one intended for catfish producers, one for catfish processors and one for catfish marketers. The survey was structured this way in order to develop a budget for the catfish industry. Issues like catfish production, catfish prices, cost of labor, cost of water, cost of land, revenues received, and income from processing and marketing were the main foci of the questionnaire.

Table 2 below shows the policy analysis matrix for catfish producers, processors and marketers in the study area. Nigeria neither imports nor exports catfish. Till date, catfish is produced, processed and marketed for local consumption purposes only. As such, this research adopted the conversion factor for all calculations. Social revenue was calculated by multiplying market revenue by the conversion factor, which is an assumed foreign exchange premium. The following ratios are used: 1.25 for revenue and tradable inputs; 1.00 for non-tradable inputs (domestic factors); 0.28 for fixed factors; and 0.37 for credit facilities (Monke and Pearson, 1989). Social costs for the items considered were also calculated the same way.

Private profitability: $\mathrm{D}=\mathrm{A}-(\mathrm{B}+\mathrm{C})$

Social profitability: $\mathrm{H}=\mathrm{E}-(\mathrm{F}+\mathrm{G})$

Output transfers: $\mathrm{I}=\mathrm{A}-\mathrm{E}$

Input transfers: $\mathrm{J}=\mathrm{B}-\mathrm{F}$

Factor transfer: $\mathrm{K}=\mathrm{C}-\mathrm{G}$

The empirical application of the Policy Analysis Matrix (PAM) begins with an assessment of revenues, costs and profits based on private (actual market) prices. Data on private revenues and costs was entered in the top row of the PAM, often termed the "private row." The private cost ratio (PCR) explains the relationship between the domestic factor cost $(\mathrm{C})$ and value added in private prices $(\mathrm{A}-\mathrm{B})$. It demonstrates the production system's ability to cover the cost of domestic factors and remain competitive. It is important for investors because they can optimize their profits by minimizing the costs of tradable inputs and factors. A PCR ratio between 0 and 1 means that agricultural goods production is profitable

Table 2. Policy Analysis Matrix (PAM)

\begin{tabular}{llllll}
\hline \multirow{2}{*}{ Items } & & Revenues & \multicolumn{2}{c}{ Production costs } & \multirow{2}{*}{ Profit } \\
\cline { 3 - 5 } & & tradable inputs & domestic factors & \\
\hline Private prices & $\mathrm{A}$ & $\mathrm{B}$ & $\mathrm{C}$ & $\mathrm{D}$ \\
Social prices & $\mathrm{E}$ & $\mathrm{F}$ & $\mathrm{G}$ & $\mathrm{H}$ & \\
Policy transfer & $\mathrm{I}$ & $\mathrm{J}$ & $\mathrm{K}$ & $\mathrm{L}$ \\
\hline
\end{tabular}

Source: Monke and Pearson, 1989. 
Table 3. Interpretation of DRC ratios

\begin{tabular}{|c|c|c|}
\hline DRC ratios & Interpretation & Conclusion \\
\hline $\mathrm{DRC}=1$ & $\begin{array}{l}\text { The economy neither gains nor saves foreign exchange } \\
\text { through domestic production }\end{array}$ & Economy in balance \\
\hline $0<\mathrm{DRC}<1$ & $\begin{array}{l}\text { Value of domestic resources used in production is below } \\
\text { the value of foreign exchange earned or saved }\end{array}$ & Comparative advantage \\
\hline $\mathrm{DRC}>1$ & $\begin{array}{l}\text { Value of domestic resources used in production is above } \\
\text { the value of foreign exchange earned or saved }\end{array}$ & No comparative advantage \\
\hline $\mathrm{DRC}<0$ & $\begin{array}{l}\text { Foreign exchange used in the production of a commodity } \\
\text { is worth more than the commodity }\end{array}$ & No comparative advantage \\
\hline
\end{tabular}

Source: Khachatryan, 2002.

for the farmer; if outside this range, the farmer makes no profit.

$$
\begin{gathered}
\mathrm{PCR}=\text { cost of non-tradable inputs } /(\text { revenues }- \text { cost of } \\
\text { tradable inputs })=\mathrm{C} /(\mathrm{A}-\mathrm{B})(1)
\end{gathered}
$$

The second step in the empirical application of the Policy Analysis Matrix (PAM) is an assessment of revenues, costs and profits in social (efficiency) prices. Data on social revenues and costs is entered to the middle row of the PAM, commonly called the "social row." To estimate the comparative advantage of a commodity (in this case, the catfish value chain), this study uses the DRC estimation described by Monke and Pearson (1989) as a ratio of the opportunity cost of domestic factors of production per unit of value added in world prices.

The DRC ratio is calculated using the following formula:

$\mathrm{DRC}=$ cost of non-tradable inputs / (revenues - cost of tradable inputs $)=\mathrm{G} /(\mathrm{E}-\mathrm{F})(2)$

The value of the DRC ratio indicates whether the production of a commodity has a comparative advantage for a given country. It estimates the efficiency of using domestic resources to save (or earn) one unit of foreign exchange. The interpretation of different DRC values is given in Table 3 .

\section{RESULTS}

\section{Profitability level and divergences in catfish} value chain systems

Table 4 reveals that the production, processing and marketing were socially profitable in the study area and earned a private profit at all value addition stages. The results showed that production was more profitable with a net private profitability of NGN $89,015.75$, followed by the marketing with NGN 5,649.51 and the processing as the least profitable with NGN 1,214.06.

Table 4. Policy Analysis Matrix for catfish value addition in Akwa Ibom State, Nigeria $(\mathrm{NGN} / \mathrm{kg})$

\begin{tabular}{lcc}
\hline \multicolumn{1}{c}{ Activities } & Private profit & Social profit \\
\hline Production & $89,015.75$ & $235,659.17$ \\
Processing & $1,214.06$ & $12,963.44$ \\
Marketing & $5,649.51$ & $11,432.63$ \\
\hline
\end{tabular}

Source: field study.

Table 5. Summary of competitiveness of the catfish value chain $(\mathrm{NGN} / \mathrm{kg})$

\begin{tabular}{lccc}
\hline \multicolumn{1}{c}{ Indicators } & Production & Processing & Marketing \\
\hline PCR & 0.61 & 0.96 & 0.59 \\
DRC & 0.17 & 0.65 & 0.34 \\
\hline
\end{tabular}

Source: field study.

\section{DISCUSSION}

At the margin in Table 4, the result indicates a positive private profit for the catfish value chain industry. The positive private profit implies that the catfish value 
chain is competitive given the current technologies, input and output prices, policies and the fact that the actors involved in the value chain are earning gainful returns. This can also be confirmed by their PCR values which are less than unity in Table 5. Table 4 also indicates a positive social profit for the catfish value chain industry in the study area. This implies that the study area made an efficient use of scarce resources in the production, processing and marketing of the commodity, and that the local population can survive without government interventions, at the margin. The results further indicate that the gains accruing to the society at each of the value chain stages are the highest in the production, followed by processing and marketing. This might be due to the fact that with good management practices, the producers have a better yield per $\mathrm{kg}$ of catfish than the processors and marketers. The result indicates that the catfish value chain in Akwa Ibom State is profitable because the ratio falls in the interval $(0-1)$. This indicates that producers, processors and marketers have positive financial incentives to continue or expand production.

The DRC coefficients for all the value chain activities were less than unity (1), thereby indicating that the value of domestic resources used is lower than value added. This implies an efficient use of domestic resources in the catfish value chain, and suggests that all activities were socially profitable. The estimated DRC ratio indicates that the value of domestic resources used in the catfish industry is below that of foreign currency earned. Consequently, Akwa Ibom State might have a comparative advantage in the catfish value chain industry. For all activities, the production was more profitable in terms of domestic factors usage, owing to their lower DRC value of 0.17 . The social benefit cost (SCB) coefficient, which is another measure for assessing the use efficiency of fixed factors, also confirmed the DRC value relating to use efficiency of domestic factors in the study area.

The private cost ratio (PCR) was estimated to measure the competitiveness of the catfish value chain and show how much the system can afford to pay domestic factors (including a normal return on capital) and still remain competitive. In the table above, the PCR value of 0.59 for marketing, 0.61 for producing and 0.96 for processing indicates that the resource cost for all the enterprises was lower than value added. This implies that they are profitable at current technology and policy intervention levels.

\section{SUMMARY AND CONCLUSIONS}

Fish production in Nigeria is significantly important to the nation's economy. The adverse variance between production and consumption implies a high growth potential in fish production. The demand for fish in Nigeria is yet to be met through domestic fish production. The catfish value chain industry in the study area was economically efficient and competitive. The study also shows that catfish value addition was efficient and competitive in the fishery industry. This justifies the need for intensified effort and policy attention on catfish value chain if Nigeria seeks to attain self-sufficiency in meeting national demand for fish. There is a need for more investment, enlightenment, and advocacy to supporting fish farmers in fully adopting the value chain of fish which will create more employment for its teeming unemployed youth.

In order to strengthen the Nigerian catfish fishery industry:

1) Priority attention should be given to all sub-sectors contributing to domestic fish production. There should more exploratory studies on capture fisheries to adequately map out the potential fishing ground in Nigerian waters.

2) The government should provide social infrastructures in rural fishing communities to encourage the teeming youth from these communities to adopt fishing as a means of livelihood.

3) As regards aquaculture, there should be an improvement in technology and resource use, and the development of additional dedicated areas. Storage and processing industries should be developed to add to the value chain in fish farming.

\section{SOURCE OF FINANCING}

Self-financed by authors.

\section{ACKNOWLEDGEMENT}

Akwa Ibom State Agricultural Development Program (AKADEP) and Department of Agricultural Economics, University of Ibadan. 


\section{REFERENCES}

Adeniyi, S. (2013). Plantain Value Chain Analysis in Ondo State, Nigeria. Unpublished Master's Thesis, Department of Agricultural and Resource Economics, Federal University of Technology, Akure.

Akande, P. O. (2018). Nigerian Catfish Value Chains. Australia Awards Short course.

Awosika, L. F. (1995). Impact of Global Climate Change and Sea Level Rise on Coastal Resources and Energy Development. DAMTECH Nigeria Limited.

Béné, C. (2006). Small-scale Fisheries: Assessing their Contribution to Rural Livelihoods in Developing Countries FAO Fisheries Circular. No. 1008. Rome: FAO

Béné, C., Macfadyen, G., Allison, E. H. (2007). Increasing the Contribution of Small-Scale Fisheries to Poverty Alleviation and Food Security. FAO Fisheries Technical Paper. No. 481. Rome: FAO.

Béné, C., Neiland, A. E. (2004). Africa's Inland Fisheries: Overview of Current Methodologies with an Emphasis on Livelihood Analysis. NAGA World Food Centre Quar. Mag., 26, 3-20.

Central Bank of Nigeria (CBN, 2015). 2015 Statistical Bulletin. Abuja, Nigeria: Central Bank Office.

Ekpo, I. E., Essien-Ibok, M.A. (2013). Development, Prospects and Challenges of Artisanal Fisheries in Akwa Ibom State, Nigeria. Int. J. Env. Sci. Manag. Eng. Res., 2(3), 69-86.

Etiosa, U., Ogbeibu, A. E. (2007). Climate Change and Poverty: Sustainable Approach in the Niger Delta Region of Nigeria. Benin City, Nigeria: Community Research and Development Centre (CREDC).

FAO (2000a). Fish production projection in Nigeria for 2000 2025. Rome: Food and Agriculture Organization.

FAO (2000b). Information on fisheries management in the federal republic of Nigeria. Retrieved from: http://www. fao.org/fi/oldsite/FCP/en/nga/body.htm

FAO (2005). Increasing the Contribution of Small-Scale Fisheries to Poverty Alleviation and Food Security. FAO Technical Guidelines for Responsible Fisheries. No. 10. Rome: Food and Agriculture Organization.

FAO (2016). The State of World Fisheries and Aquaculture 2016. Contributing to Food Security and Nutrition for all. Rome: Food and Agriculture Organization.

FAO (2020). Nigeria at a glance. Food and Agriculture Organization Nigeria. Retrieved from: http://www.fao.org/ nigeria/fao-in-nigeria/en/

FAOSTAT (2018). The Food and Agriculture Organization Corporate Statistical Database. Retrieved from: http:// www.fao.org/faostat/en/\#home

FDF (2018). Federal Department of Fisheries report.
Fishery Committee for the West Central Gulf of Guinea (2016). Nigeria Fishery Statistics - 2016 Summary Report. Retrieved Aug 20 2016 from: http://www.fcwcfish. $\mathrm{org} /$ fisheries/statistics/nigeria/901-nigeria-fisherystatistics-2016-summary-report

Flake, L., Nzeke, U. (2007). Nigeria Fishery Products: Nigeria's Fish Market USDA Foreign Agricultural Service, Global Agricultural Information Network (GAIN) Report, No. N17026.

Inoni, O. E. (2007). Allocative Efficiency in Pond Fish Production in Delta State, Nigeria: A Production Function Approach. Trop. Subtrop., 40(2), 127-134.

Khachatryan, N. (2002). Assessing the market potential of brandy produced in Armenia. Stuttgart, Germany: University of Hohenheim.

Monke, E., Pearson, S. (1989). The Policy Analysis Matrix for Agricultural Development. Ithaca, London: Cornell University Press.

National Bureau of Statistics (2013). Unemployment in Nigeria. Retrieved May 24 2013 from: www.nigerianstat. gov.ng

National Bureau of Statistics (2016). Unemployment/underemployment watch: Q1 2016. Retrieved Dec 6 $6^{\text {th }} 2016$ from: https://www.google.com.ng/webhp?sourceid=chr omeinstant\&ion $=1 \&$ espv $=2 \&$ ie $=U T F \& \# q=$ unemployme nt $\% 20$ rate $\% 20 \mathrm{in} \% 20$ nigeria $\% 202016$

NPC (National Population Commission). (2006). Nig. Ann. Cens. Bull., 10(2), 23-27.

Ogundari, K., Ojo, S. O. (2009). An Examination of Income Generation Potential of Aquaculture Farms in Alleviating Household Poverty: Estimating and Policy Implications for Nigeria. Turk. J. Fish. Aquat. Sci., 9, 39-45.

Okezie, C. A., Igwe, K. C., Nnabugwu, P. O., Okezie, C. R. (2008). Harnessing of Potentials of Agriculture for Food Security in Abia State, Nigeria. In: E. A. Aiyeduru, P. O. Idisi, J. N. Nmadu (Eds.). Agricultural Technology and Nigerian Economy Development. Proceedings of 10th Annual National Conference of the NAEE, 7th-10th Oct. 2008.

Olawumi, A. T., Dipeolu, A. O., Bamiro, O. M. (2010). Economic Analysis of Homestead Fish Farming in Ogun State, Nigeria. J. Human Ecol., 31(1), 13-17. Retrieved from: https://dx.doi.org/10.1080/09709274.2010.119062 92

Onojeghuo, A. O., Blackburn, A. G. (2011). Forest in an Ecologically Important Region: Patterns and Causes for Landscape Dynamics in the Niger Delta. Ecol. Ind., 11, 1437-1446. Retrieved from: https://dx.doi.org/10.1016/j. ecolind.2011.03.017

SEEDS (2015). Akwa Ibom State Economic Empowerment and Development Strategy. 
Obot, A., Ogonna, O., Precious, Ch., Essien, A. (2020). Analysis of catfish value chain in Akwa Ibom State, Nigeria. J. Agribus. Rural Dev., 1(55), 53-60. http://dx.doi.org/10.17306/J.JARD.2020.01305

UNEP (United Nations Environment Programme). (2011). Environmental Assessment of Ogoniland. UNEP Report.

Uyigue, E., Agho, M. (2007). Coping with Climate Change and Environmental Degradation in the Niger Delta of
Southern Nigeria. Benin, Nigeria: Community Research and Development Centre.

WorldFish (2018). WorldFish Nigeria Strategy: 2018-2022. Penang, Malaysia. 